\title{
FAKTOR-FAKTOR YANG MEMPENGARUHI JUMLAH SISA LEBIH PERHITUNGAN ANGGARAN (SiLPA) ANGGARAN PENDAPATAN DAN BELANJA DAERAH PADA PEMERINTAH PROVINSI RIAU
}

\author{
Ikhwani Ratna, SE, M.Si, Ak \\ Fakultas Ekonomi dan Ilmu Sosial
}

\begin{abstract}
This study aims to prove (1) The Effect of Planning Documents Against SiLPA The Effect of Recording of SiLPA Administration (3) Effect of Employee Competence on SiLPA. This study uses descriptive analysis method and to test the hypothesis used multiple linear regression analysts. This research was conducted on 37 SKPD in the Riau Provincial Government. And for the sample from this study taken from all SKPD in the Riau Provincial Government environment. Data collection for variables $\mathrm{X} 1, \mathrm{X} 2$ and $\mathrm{X} 3$ uses a questionnaire, while for variable $\mathrm{Y}$ comes from secondary data obtained from LAKIP.

The results of this study indicate that Registration of Administration and Competence of Employees can increase SiLPA in the Government of Riau Province. Whereas Partial Planning Documents cannot increase the SiLPA Regional Work Unit (SKPD).
\end{abstract}

\begin{abstract}
Abstrak
Penelitian ini bertujuan membuktikan (1) Pengaruh Dokumen Perencanaan Terhadap SiLPA Pengaruh Pencatatan Adminsitrasi Terhadap SiLPA (3) Pengaruh Kompetensi Pegawai terhadap SiLPA. Penelitian ini menggunakan metode analisis deskriptif dan untuk menguji hipotesis digunakan analis regresi linear berganda. Penelitian ini dilakukan terhadap 37 SKPD di lingkungan Pemerintah Provinsi Riau. Dan untuk sampel dari penelitian ini diambil dari seluruh SKPD yang ada di lingkunga Pemerintah Provinsi Riau tersebut. Pengumpulan data untuk variabel X 1, X 2 dan X3 menggunakan kuesioner, sedangkan untuk variabel Y berasal dari data sekunder yang diperoleh dari LAKIP.

Hasil penelitian ini menunjukkan bahwa Pencatatan Adminsitrasi dan Kompetensi Pegawai dapat meningkatkan SiLPA pada Pemerintah Provinsi Riau. Sedangkan Dokumen Perencanaan secara parsial tidak dapat meningkatkan SiLPA Satuan Kerja Perangkat Daerah (SKPD) .

\section{Pendahuluan}

Undang-Undang Nomor 32 Tahun 2004 tentang Pemerintahan Daerah dan Undang- Undang Nomor 33 Tahun 2004 tentang Perimbangan Keuangan antara Pemerintah Pusat dan Pemerintah Daerah membuka peluang yang luas bagi daerah
\end{abstract}


untuk mengembangkan dan membangun daerahnya sesuai dengan kebutuhan dan prioritasnya masing-masing. Dengan berlakunya kedua undang-undang tersebut di atas membawa konsekuensi bagi daerah dalam bentuk pertanggungjawaban atas pengalokasian dana yang dimiliki dengan cara yang efisien dan efektif, khususnya dalam upaya peningkatan kesejahteraan dan pelayanan umum kepada masyarakat. Dalam pengelolaan anggaran daerah, terkadang masih ditemukan kelemahan baik dari sisi perencanaan, pelaksanaan, pelaporan, dan pertanggungjawaban. Hal ini dapat dilihat dari banyaknya daerah yang terlambat dalam pengesahan APBD . Lambatnya pengesahan APBD oleh DPRD ini berakibat terhadap terhambatnya realisasi anggaran. Sehingga banyak daerah yang baru bisa merealisasikan anggarannya pada pertengahan tahun anggaran. Lambatnya realisasi APB ini juga berdampak terhadap pembangunan di daerah tersebut. Anggaran yang tidak terealisasi tersebut, pada akhir tahun anggaran menjadi Sisa Lebih Perhitungan Anggaran (SILPA).

Era otonomi daerah yang sudah berlangsung lebih dari satu dasawarsa telah memberiruang kepada daerah untuk memakai tiga model pilihan dalam penganggaran yaitu surplus, defisit dan berimbang antara pendapatan dan belanja. Hal ini ditetapkan berdasarkan pertimbangan jumlah pendapatan dan belanja daerah. Surplus/defisit merupakan imbas dari perbedaan antara pendapatan dan belanja. Belanja yang lebih besar dari pendapatan akan menimbulkan defisit, sedangkan pendapatan yang lebih besar dari belanja akan menghasilkan surplus. Selain itu, dalam Undang-Undang Nomor 17 Tahun 2003 tentang Keuangan Negara diamanatkan bahwa jika terdapat surplus/defisit diharuskan dianggarkan pembiayaan, baik sumber-sumber Penerimaan Pembiayaan yang akan digunakan menutup defisit dan Pengeluaran Pembiayaan guna menyalurkan surplus anggaran. Dalam APBD 2014 sebagian besar daerah menganggarkan defisit di mana sumber utama Penerimaan Pembiayaan berasal dari Sisa Lebih Perhitungan Anggaran (SiLPA) tahun sebelumnya.

Data APBD menunjukkan bahwa adanya kecenderungan daerah untuk menganggarkan defisit dalam APBD-nya. Hal ini terlihat dari 491 kabupaten/ kota dan 33 provinsi di Indonesia pada Tahun Anggaran (TA) 2014 sebanyak 457 daerah menganggarkan defisit dalam APBD-nya, jika melihat data ini maka terjadi peningkatan dari tahun sebelumnya yang hanya 447 daerah yang menganggarkan defisit. Sedangkan daerah yang menganggarkan surplus di tahun 2014 sebanyak 56 daerah, sehingga turun dari tahun sebelumnya yang berjumlah 68 daerah dan 
sisanya sebanyak 11 daerah mempunyai anggaran pendapatan dan belanja yang bernilai sama atau berimbang.

Fenomena ini menarik untuk dicermati. Jika dilihat dari data APBD yang telah masuk, kecenderungan daerah menganggarkan defisit tersebut karena adanya SiLPA dalam APBD mereka, artinya sebenarnya secara umum daerah tidak sedang dalam kondisi defisit secara riil, mereka menganggarkan defisit karena untuk menyerap SiLPA tahun sebelumnya. Hal lain yang juga menarik untuk dicermati adalah bahwa pada umumnya daerah terbukti mengalami surplus pada saat realisasi.

Rata-rata rasio defisit secara nasional (agregat provinsi, kabupaten, dan kota) adalah 7,5\% dengan kontribusi SiLPA untuk menutup defisit tersebut sekitar 91,3\% sedangkan kontribusi penerimaan pinjaman dan obligasi daerah 5,9\%. Provinsi Kalimantan Timur merupakan daerah dengan rasio defisit terbesar di mana faktor utama penyebab hal tersebut adalah untuk mengakomodasi SiLPA tahun sebelumnya yang jumlahnya cukup besar agar bisa digunakan dalam belanja publik. Begitu juga dengan Provinsi Riau yang memiliki defisit anggaran terbesar ke dua secara nasional, dimana defisit APBD Pemerintah Provinsi dan Kab/kota nya secara rata-rata sebesar 18, $57 \%$. Sebagian besar defisit pada APBD di Provinsi Riau disebabkan untuk mengakomodasi SILPA tahun sebelumnya dimana kontribusi menutup defisit sebesar 95,8\%.

Pelampauan pendapatan ataupun penghematan belanja pada realisasi APBD sebelumnya akan menghasilkan sisa dana. Sisa dana tersebut dinamakan Sisa Lebih Perhitungan Anggaran yang biasa disingkat SiLPA. Namun karena APBD TA 2012 dibuat sebelum berakhirnya tahun anggaran maka SiLPA yang terdapat di APBD merupakan nilai estimasi. Semakin besar SiLPA menunjukkan kekurangcermatan dalam penganggaran (perencanaan yang kurang baik) atau kelemahan dalam pelaksanaan anggaran. Sehingga rasio SiLPA terhadap belanja menunjukkan porsi belanja yang tertunda atau anggaran yang tidak terserap.

Rasio SiLPA terhadap belanja selain menggambarkan besaran belanja yang tertunda pelaksanaannya pada tahun sebelumnya juga menggambarkan jumlah realisasi pendapatan tahun anggaran sebelumnya lebih besar dari proyeksinya. Rata-rata rasio SiLPA terhadap belanja daerah secara agregat provinsi, kabupaten 
dan kota adalah 7,4\% dengan rasio tertingginya adalah Provinsi Kalimantan Timur $(25,5 \%)$. Sebanyak 12 provinsi mempunyai rasio di atas rata-rata dan 21 provinsi di bawah rata-rata. Sedangkan untuk Provinsi Riau sendiri juga memiliki SILPA yang cukup besar dimana secara nasional berada pada peringkat dua dengan rasio terhadap belanja daerah pada tahun 2014 sebesar 19,4\%. Hal ini sebagai suatu indikasi masih lemahnya penyerapan APBD di Provinsi Riau yang bisa saja terjadi karena birokrasi yang berbelit ataupun permasalahan lambatnya pengesahan anggaran.

Fenomena yang penulis kemukakan di atas menjadi suatu pertanda bahwa APBD yang telah disusun dalam rangka mendukung tercapainya visi misi Riau 2020 masih memiliki banyak kelemahan. Diantaranya adalah masih besarnya defisit APBD di Provinsi Riau akibat SILPA yang besar dari tahun sebelumnya. Hal ini menunjukkan bahwa dalam pengelolaan APBD perlu dicermati proses nya penyusunannya agar anggaran yang disusun dapat dimanfaatkan secara maksimal.

Berdasarkan fenomena di atas, maka penulis tertarik untuk membuat penelitian dengan judul "Faktor-Faktor Yang Mempengaruhi Jumlah Sisa Lebih Perhitungan Anggaran (SILPA) pada Anggaran Pendapatan dan Belanja Daerah Pemerintah Provinsi Riau".

\section{Rumusan Masalah}

Berdasarkan uraian latar belakang di atas, maka rumusan masalah dalam penlitian ini adalah sebagai berikut :

1. Bagaimana pengaruh Dokumen Perencanaan secara parsial terhadap SiLPA.

2. Bagaimana pengaruh Pencatatan Adminsitrasi secara parsial terhadap SiLPA.

3. Bagaiamana pengaruh Kompetensi SDM parsial terhadap SiLPA.

4. Bagaimana pengaruh Dokumen Perencanaan, Pencatatan Adminsitrasi , dan Kompetensi SDM secara simultan berpengaruh terhadap SiLPA.

\section{Telaah Pustaka}

\section{A. Anggaran Pendapatan dan Belanja Daerah}


Anggaran Pendapatan dan Belanja Daerah (APBD) pada hakekatnya merupakan salah satu instrumen kebijakan yang dipakai sebagai alat untuk meningkatkan pelayanan umum dan kesejahteraan masyarakat di daerah.

Menurut Halim (2004 : 15) : Anggaran Pendapatan dan Belanja Daerah (APBD) adalah suatu Anggaran daerah yang memiliki unsur-unsur sebagai berikut : rencana kegiatan suatu daerah, beserta uraiannya secara rinci; adanya sumber penerimaan yang merupakan target minimal untuk menutupi biaya-biaya sehubungan dengan aktivitas-aktivitas tersebut, dan adanya biaya-biaya yang merupakan batas maksimal pengeluaran-pengeluaran yang akan dilaksanakan; jenis kegiatan dan proyek yang dituangkan dalam bentuk angka; periode anggaran, yaitu biasanya 1 (satu) tahun.

Pendapatan dibagi menjadi 3 kategori yaitu pendapatan Asli Daerah (PAD), Dana Perimbangan, dan lain-lain pendapatan daerah yang sah. Belanja digolongkan menjadi 4 yakni belanja aparatur daerah, belanja pelayanan publik, belanja bagi hasil dan bantuan keuangan, dan belanja tak tersangka. Belanja aparatur daerah diklasifikasi menjadi 3 kategori yaitu belanja administrasi umum, belanja operasi dan pemeliharaan, dan belanja modal. Pembiayaan dikelompokkan menurut sumber-sumber pembiayaan yaitu : sumber penerimaan daerah dan sumber pengeluaran daerah. Sumber pembiayaan berupa penerimaan daerah adalah : sisa lebih anggaran tahun lalu, penerimaan pinjaman dan obligasi, hasil penjualan aset daerah yang dipisahkan dan transfer dari dana cadangan. Sumber pembiayaan berupa pengeluaran daerah terdiri atas : pembayaran utang pokok yang telah jatuh tempo, penyertaan modal, transfer ke dana cadangan, dan sisa lebih anggaran tahun sekarang. (Halim, 2004 : 18).

\section{B. Pengertian SILPA}

Pelampauan pendapatan ataupun penghematan belanja pada realisasi APBD sebelumnya akan menghasilkan sisa dana. Sisa dana tersebut dinamakan Sisa Lebih Perhitungan Anggaran yang biasa disingkat SiLPA. Semakin besar SiLPA menunjukkan kekurangcermatan dalam penganggaran (perencanaan yang kurang 
baik) atau kelemahan dalam pelaksanaan anggaran. Sehingga rasio SiLPA terhadap belanja menunjukkan porsi belanja yang tertunda atau anggaran yang tidak terserap.

SiLPA (dengan huruf i kecil) adalah Sisa Lebih Perhitungan Anggaran, yaitu selisih lebih realisasi penerimaan dan pengeluaran anggaran selama satu periode anggaran. Misalnya realisasi penerimaan daerah tahun anggaran 2008 adalah Rp571 milyar sedangkan realisasi pengeluaran daerah adalah Rp524 milyar, maka SiLPA-nya adalah Rp47 milyar.

Sedangkan SILPA (dengan huruf i besar/kapital) adalah Sisa Lebih Pembiayaan Anggaran Tahun Berkenan. Yaitu selisih antara surplus/defisit anggaran dengan pembiayaan netto. Dalam penyusunan APBD angka SILPA ini seharusnya sama dengan nol. Artinya bahwa penerimaan pembiayaan harus dapat menutup defisit anggaran yang terjadi.

Jika angka SILPA-nya positif berarti bahwa ada pembiayaan netto setelah dikurangi dengan defisit anggaran, masih tersisa (misalnya (Rp2 milyar). Atau dengan penjelasan lain bahwa secara anggaran masih ada dana dari penerimaan pembiyaan yang Rp2 milyar tersebut yang belum dimanfaatkan untuk membiayai Belanja Daerah dan/atau Pengeluaran Pembiayaan Daerah.

Jika angka SILPA-nya negatif berarti bahwa pembiayaan netto belum dapat menutup defisit anggaran yang terjadi. Untuk itu perlu dicari jalan keluarnya. Misalnya dengan mengusahakan sumber-sumber penerimaan pembiayaan yang lain seperti utang dan lain sebagainya. Atau dengan mengurangi Belanja dan atau pengeluaran pembiayaan sehingga angka SILPA ini sama dengan nol.

Dari uraian di atas tergambar bahwa salah satu sumber pembiayaan daerah untuk menutup defisit anggaran adalah Sisa Lebih Perhitungan Anggaran (SiLPA) daerah tahun sebelumnya. Sesuai dengan data dari website Dirjen Perimbangan Keuangan Departemen Keuangan RI pada tahun anggaran 2009, hampir semua APBD Provinsi dan Kabupaten/Kota di Indonesia APBDnya mengalami defisit. Namun setelah ditelusuri lebih lanjut kebanyakan (tidak semua) defisit tersebut ternyata sama dengan SilPA tahun anggaran sebelumnya (2008). Artinya bahwa defisit APBD Provinsi dan Kabupaten/Kota tersebut "aman" dalam arti telah tertutup tanpa 
melakukan pinjaman atau upaya lain seperti pencairan dana cadangan, menjual kekayaan daerah yang dipisahkan atau penerimaan kembali pemberian pinjaman.

\section{Faktor-faktor yang Mepengaruhi SiLPA}

Ada beberapa faktor yang mempengaruhi SiLPA, diantaranya jika ditinjau dari aspek dokumen perencanaan, pencatatan administrasi dan kompetensi sumber daya manusia. Untuk lebih jelasnya dapat dilihat pada uraian berikut ini :

\section{1) Dokumen Perencanaan}

Dokumen perencanaan di daerah menurut Pinto (2013) terdiri dari:

1) Rencana Pembangunan Jangka Panjang Daerah (RPJPD)

Rencana Pembangunan Jangka Panjang Daerah (RPJPD) merupakan rencana untuk mencapai tujuan dibentuknya pemerintahan daerah provinsi sesuai UndangUndang tentang Pembentukan Daerah.

2) Rencana Pembangunan Jangka Menengah (RPJM) Daerah

Rencana Pembangunan Jangka Menengah (RPJM) Daerah merupakan arah pembangunan yang ingin dicapai daerah dalam kurun waktu 5 (lima) tahun, sesuai masa bhakti Kepala Daerah terpilih yang disusun berdasarkan visi, misi, dan program Kepala Daerah.

3) Rencana Strategis (Renstra) Satuan Kerja Perangkat Daerah

Renstra SKPD adalah dokumen perencanaan SKPD yang berjangka waktu 5 (lima) tahun, disusun dalam rangka mengoperasionalkan RPJM Daerah sesuai tugas dan fungsi masing-masing SKPD sesuai bidang urusan yang menjadi kewenangan daerah.

4) Rencana Kerja Pemerintah (RKP) Daerah

RKP Daerah yang merupakan rencana pembangunan tahunan daerah, wajib disusun oleh Daerah sebagai landasan dalam penyusunan anggaran pendapatan dan belanja daerah (APBD)

5) Rencana Kerja (Renja) Satuan Kerja Perangkat Daerah

Renja SKPD merupakan dokumen rencana pembangunan masing-masing SKPD yang berjangka waktu 1 (satu) tahun, memuat kebijakan, program, dan kegiatan yang disusun sesuai dengan tugas dan fungsi SKPD yang bersangkutan berdasarkan 
urusan yang menjadi kewenangan daerah, sasaran (indikator) hasil dan keluaran yang terukur, beserta rincian pendanaannya.

\section{2) Pencatatan Administrasi}

Administrasi dalam arti sempit. Menurut Handayaningrat (1988:2) mengatakan "Administrasi secara sempit berasal dari kata Administratie (bahasa Belanda) yaitu meliputi kegiatan cata-mencatat, surat-menyurat, pembukuan ringan, ketikmengetik, agenda dan sebagainya yang bersifat teknis ketatausahaan". Dari definisi tersebut dapat disimpulkan administrasi dalam arti sempit merupakan kegiatan ketatausahaan yang mliputi kegiatan cata-mencatat, surat-menyurat, pembukuan dan pengarsipan surat serta hal-hal lainnya yang dimaksudkan untuk menyediakan informasi serta mempermudah memperoleh informasi kembali jika dibutuhkan. Administrasi dalam arti luas. Menurut Gie (1980) mengatakan "Administrasi secara luas adalah serangkaian kegiatan yang dilakukan oleh sekelompok orang dalam suatu kerjasama untuk mencapai tujuan tertentu". Administrasi secara luas dapat disimpulkan pada dasarnya semua mengandung unsur pokok yang sama yaitu adanya kegiatan tertentu, adanya manusia yang melakukan kerjasama serta mencapai tujuan yang telah ditentukan sebelumnya. Administrasi pada intinya melingkupi seluruh kegiatan dari pengaturan hingga pengurusan sekelompok orang yang memiliki diferensiasi pekerjaan untuk mencapai suatu tujuan bersama. Administrasi dapat berjalan dengan suatu atau banyak orang terlibat di dalamnya.

\section{3) Kompetensi Sumber Daya Manusia}

Menurut Nawawi (2001) ada tiga pengertian Sumber Daya Manusia yaitu:

1) Sumber daya manusia adalah manusia yang bekerja dilingkungan suatu organisasi (disebut juga personil, tenaga kerja, pekerja atau karyawan).

2) Sumber daya manusia adalah potensi manusiawi sebagai penggerak organisasi dalam mewujudkan eksistensinya.

3) Sumber daya manusia adalah potensi yang merupakan aset dan berfungsi sebagai modal (non material/non finansial) di dalam organisasi bisnis, yang dapat mewujudkan menjadi potensi nyata (real) secara fisik dan non-fisik dalam mewujudkan eksistensi organisasi. 
Pengaruh yang ditimbulkan oleh pengelolaan anggaran dan SDM yang salah sangat banyak seperti contohnya pada aspek ekonomi, dimana karena adanya kesalahan pengelolaan anggaran dan penetapan SDM yang salah maka kualitas dari pelayanan akan menurun. Dalam hal ini proses perekonomian Indonesia akan lambat karena ketidakmampuan SDM dalam mengelola dengan baik. Di era globalisasi ini tentunya Pemerintah Indonesia sangat membutuhkan SDM yang mampu mengelola anggaran dengan baik.

KKN merupakan sebuah penyakit yang krusial yang sangat-sangat membunuh perekonomian Indonesia. SDM yang melimpah tidak bisa dikelola dengan baik oleh aparatur pemerintah (SDM) karena kualitasnya kurang. Kualitas SDM yang rendah juga membuat sebuah proses yang lambat dalam pelayanan administrasi, contohnya dalam mengurus izin usaha

\section{Kerangka Pemikiran}

Berdasarkan landasan teori dan rumusan masalah penelitian, penulis mengidentifikasikan 3 (tiga) independen variabel (X) yang diperkirakan baik secara langsung maupun tidak langsung berpengaruh terhadap SiLPA. Model penelitian tersebut dapat dilihat pada gambar berikut ini :

Variabel independen Variabel Dependen

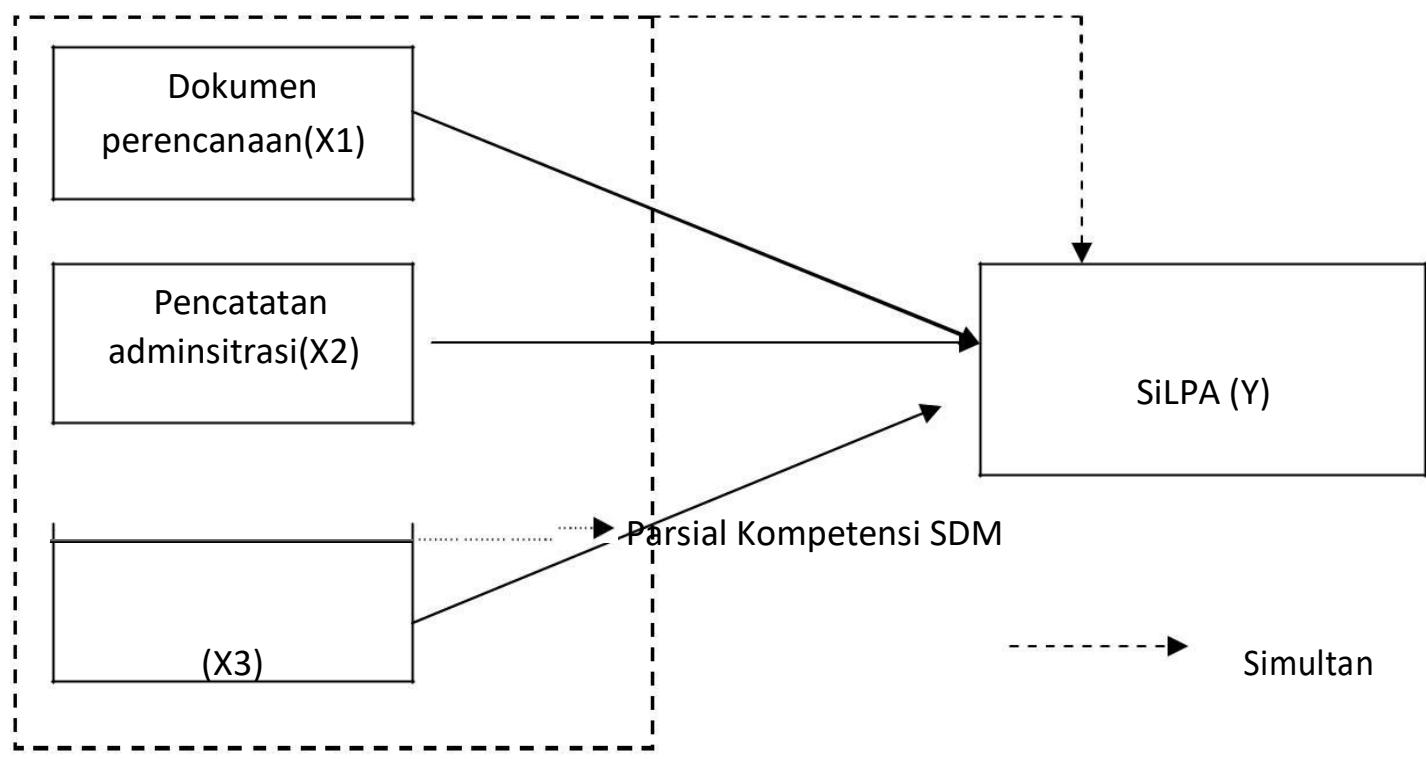


SiLPA (Y) dipengaruhi baik secara langsung maupun tidak langsung dipengaruhi oleh beberapa variabel independen (X) yaitu Dokumen Perencanaan (X1),Pencatatan Adminsitrasi (X2), kompetensi SDM (X3) dengan uraian sebagai berikut :

a. Dokumen Perencanaan maka semakin tinggi SiLPA di Pemerintah Provinsi Riau.

b. Semakin tinggi Pencatatan Administrasi maka semakin tinggi SiLPA di Pemerintah Provinsi Riau.

c. Semakin banyak Kompetensi SDM maka semakin tinggi SiLPA di Pemerintah Provinsi Riau.

\section{Hipotesis Penelitian}

Hipotesis dalam penelitian ini dikembangkan dari telaahan teoritis dan peneliti terdahulu sebagai jawaban sementara dari masalah yang memerlukan pengujian secara empiris. Dengan demikian dikemukakan hipotesis yang berkaitan dengan penelitian ini, yaitu :

\section{Ha : "Dokumen Perencanaan,Pencatatan Administrasi dan Kompetensi SDM}

\section{berpengaruh secara simultan maupun parsial terhadap SiLPA di} Pemerintah

\section{Provinsi Riau."}

\section{Metode Penelitian}

\section{A. Populasi dan Sampel Penelitian}

Populasi adalah suatu kelompok dari elemen penelitian, dimana elemen adalah unit terkecil yang merupakan sumber dari data yang diperlukan (Mudrajat Kuncoro, 2003). Populasi dalam penelitian ini adalah 37 SKPD yang ada pada Pemerintah Provinsi Riau. Semua populasi dijadikan sampel (sensus), masing-masing SKPD diwakili oleh 1 orang.

\section{B. Jenis dan Sumber Data}

Jenis dan sumber data dalam penelitian ini meliputi

1. Data Primer, yaitu data yang diperoleh atau dikumpul langsung dari sumber penelitian atau lapangan yang diperoleh melalui pengamatan dan pencatatan 
secara cermat di SKPD yang ada di Pemerintah Provinsi Riau. Data primer yang digunakan dalam penelitian ini bersumber dari kuisioner yang disebar ke 37 SKPD yang ada lingkungan Pemerintah Provinsi Riau.

2. Data sekunder, yaitu data yang diperoleh dari catatan, dokumen yang ada di SKPD Pemerintah Provinsi Riau. Data sekunder yang digunakan dalam penelitian ini bersumber dari Laporan Akuntabilitas Kinerja Instansi Pemerintah (LAKIP) Tahun 2013 dan Laporan Keuangan Pemerintah Provinsi Riau Tahun 2013.

3. Informan Penelitian

Informan penelitian adalah nara sumber yang di jadikan langsung oleh penulis sebagai tempat untuk memperoleh informasi yg berkaitan dengan penelitian. Adapun informan penelitian ini terdiri atas :

a. Kepala Biro Keuangan Provinsi Riau

b. Kepala sub bagian keuangan dan perlengkapan setiap SKPD se Provinsi Riau

\section{Metode Analisa Data}

Metode analisis data yang digunakan dalam penelitian ini adalah menggunakan analisis regresi berganda. Analisis ini digunakan untuk mengetahui tingkat signifikansi masing-masing variabel independen. Model analisa Regresi linear berganda dalam penelitian ini dapat dirumuskan sebagai berikut :

$$
\mathbf{Y}=\mathbf{b}_{0}+\mathbf{b}_{1} \mathbf{X}_{1}+\mathbf{b}_{2} \mathbf{X}_{2}+\mathbf{b}_{3} \mathbf{X}_{3}+\mathbf{e}
$$

Dimana :

$\begin{array}{ll}\mathrm{Y} & =\text { SiLPA } \\ \mathrm{b}_{0} & =\text { Konstanta } \\ \mathrm{b}_{1} \mathrm{~b}_{2}, \mathrm{~b}_{3}, \mathrm{~b}_{4} & =\text { Koefisien Regresi } \\ \mathrm{X}_{1} & =\text { Dokumen Perencanaan } \\ \mathrm{X}_{2} & =\text { Pencatatan Administrasi } \\ \mathrm{X}_{3} & =\text { Kompetensi SDM } \\ \mathrm{e} & =\text { Error }\end{array}$

\section{Uji kualitas data}


Dalam suatu penelitian, kesimpulan yang diambil akan sangat tergantung pada kualitas data yang dianalisis dan instrumen yang digunakan untuk mengumpulkan data penelitian, karena itu ada dua konsep yang dapat digunakan untuk mengukur kualitas data, yaitu : validitas dan reliabilitas.

Menurut Sujoko Efferin (2008: 13) validasi data adalah "kebenaran" sebuah data,yaitu sejauh mana sebuah data secara akurat menggambarkan fenomena sosial yang dirujuk. Instrumen yang valid berarti alat ukur yang digunakan untuk mendapatkan data (mengukur) itu valid. Valid berarti instrumen tersebut dapat digunakan untuk mengukur apa yang seharusnya diukur.

Menurut Sujoko Efferin (2008) reliabilitas data adalah sejauh mana konsistensi kategorisasi data jika dilakukan oleh peneliti yang lain atau oleh peneliti yang sama dalam kejadian yang berbeda. Instrumen yang reliabel adalah instrumen yang bila digunakan beberapa kali untuk mengukur objek yang sama akan menghasilkan data yang sama. Jika alat ukur yang digunakan tidak sahih dan tidak andal maka hasilnya tidak menggambarkan keadaan yang sesungguhnya. Untuk itu diperlukan dua macam pengujian yaitu uji kesahihan (test of validity) dan uji keandalan (test of realibility).

\section{E. Deskripsi Hasil Penelitian}

Analisis Deskriptif membahas kesimpulan yang penulis peroleh atas kecenderungan responden dalam menjawab kuesioener yang diajukan. Dalam penelitian ini kuesioner dirancang dengan teknik skala Likert. Dalam metode skala likert terdapat ítem-item pernyataan yang bersifat unfavourable, yaitu pernyataanpernyataan yang bersifat mendukung, dan pernyataan-pernyataan unfavourable, yaitu pernyataan-pernyataan yang bersifat tidak mendukung.

Untuk memberikan gambaran tentang variabel yang diteliti yaitu SiLPA, Dokumen Perencanaan,Pencatatan Administrasi dan Kompetensi SDM, data hasil skor jawaban responden yang dikumpulkan melalui kuesioner penelitian dikategorikan menggunakan distribusi rentang antar kuartil. 
Untuk data ordinal atau data interval/ratio yang memiliki distribusi asimetris, ukuran pemusatan dapat dilakukan melalui distribusi rentang antar kuartil (Cooper, 2006 : 467).

Pada distribusi yang berurutan, nilai kuartil I, Kuartil II dan Kuartil III dapat ditentukan melalui perhitungan sebagai baerikut :

Kuartil II $($ Median $)=[$ Skor minimum + skor maksimum $]: 2$

Kuartil I $=[$ Skor minimum + median $]: 2$

Kuartil III $=[$ median + skor maksimum $]: 2$

Skor minimum $=$ skor terendah $\mathrm{x}$ jumlah pertanyaan $\mathrm{x}$ jumlah responden Skor maksimum $=$ skor teringgi $\mathrm{x}$ jumlah pertanyaan $\mathrm{x}$ jumlah responden

\section{F. Pengujian Hipotesis}

Pengujian terhadap hipotesis penelitian dilakukan melalui pengujian model regresi dan pengujian pengaruh parsial masing-masing variabel bebas. Pengujian model regresi dimaksudkan untuk menguji pengaruh secara simultan seluruh variabel bebas. Pengujian model regresi dilkukan dengan uji F, sedangkan pengujian pengaruh parsial dilkukan dengan uji t.

\section{Uji signifikansi secara simultan dilakukan dengan Uji F}

Uji F dilakukan untuk menguji apakah variabel bebas secara simultan berpengaruh terhadap variabel terikat. Hasil uji F pada output SPSS dapat dilihat pada tabel anova (Nugroho, 2005). Pedoman yang digunakan untuk menerima atau menolak hipotesis :

a. Jika F hitung < F tabel atau thitung < t tabel atau nilai $\mathrm{p}$-value $>$ level of significant $(\alpha)$,maka Ho diterima Ha ditolak.

b. Jika F hitung > F tabel atau t hitung $>\mathrm{t}$ tabel atau nilai $\mathrm{p}$-value $<$ level of significant

( $\alpha)$, maka Ho ditolak Ha diterima.

Tingkat signifikansi yang digunakan adalah 0,05 yang lazim digunakan dalam penelitian ilmu-ilmu sosial. Apabila $\mathrm{F}$ hitung $>\mathrm{F}$ tabel, maka terdapat pengaruh variabel bebas terhadap variabel terikatnya.

\section{Uji signifikansi secara parsial dilakukan dengan uji t (t-test)}


Uji parsial dengan menggunakan t-test dilakukan untuk menguji pengaruh semua variabel bebas secara parsial terhadap variabel terikat. Uji $t$ ini membandingkan $t$ hitung dengan $t$ tabel yaitu bila $t$ hitung $>t$ tabel berarti bahwa variabel bebas mempunyai pengaruh bermakna terhadap variabel terikat. Sebaliknya jika t hitung < t tabel maka variabel bebas tidak mempunyai pengaruh terhadap variabel terikat, dalam hal ini tingkat kepercayaan $\alpha$ sebesar 0,05 (5\%).

\section{Uji Koefisien determinasi}

Uji koefisien determinasi $\left(\mathrm{R}^{2}\right)$ digunakan untuk mengukur seberapa besar variasi dalam varibel bebas dalam menjelaskan bersama-sama varibel terikat atau seberapa baik model regresi yang telah dibuat tersebut cocok dengan data. Semakin besar koefisien determiansinya, maka semakin baik varibel bebas dalam menjelaskan variabel terikatnya. Dengan demikian persamaan regresi yang yang dihasilkan baik untuk mengestimasi nilai variabel terikat

\section{Hasil Penelitian}

\section{A. Pengujian validitas dan reliabilitas data}

Sebelum data dianalisa dilakukan pengujian terhadap instrument penelitian yang dipakai atau jenis data yang dihimpun dilapangan atau uji validitas dan reliabilitas data. Uji ini perlu dilakukan untuk melihat keabsahan atau keakuratan data.

\section{Uji validitas}

Pengujian validitas instrument dengan menggunakan software SPSS 17, nilai vailiditas dapat dilihat pada kolom corrected item-total correlation. Jika angka korelasi yang diperoleh lebih besar daripada angka kritik ( $r$ hitung $>r$ tabel ) maka instrument tersebut dikatakan valid. Berdasarkan hasil uji validitas dapat disimpulkan bahwa tidak seluruh item pertanyaan untuk mengukur masing-masing variabel penelitian dinyatakan valid. Hal ini dapat dilihat bahwa tidak seluruh $r$ hitung lebih besar daripada $\mathrm{r}$ tabel. Dimana nilai $r$ Tabel untuk sampel sebanyak 37 adalah 0,296. 
Berdasarkan hasil uji validitas untuk variabel Dokumen Perencanaan, Pencatatan Administrasi,Kompetensi SDM dapat disimpulkan bahwa semua item pertanyaan valid. Hal ini dapat dilihat bahwa $r$ hitung pertanyaan tersebut lebih besar daripada nilai $r$ tabel. Dimana $r$ tabel untuk sampel sebanyak 37 adalah 0,296. Ini berarti bahwa item pertanyaan tersebut dapat mengukur apa yang hendak diukur atau dengan kata lain dapat mengungkapkan apa yang hendak diungkapkan pada variabel yang diukur, maka hasilnya juga tidak dapat menggambarkan keadaan sesungguhnya. Sehingga untuk pengolahan data selanjutnya, ke item pertanyaan tersebut dapat dipakai .

\section{Uji Reliabilitas}

Setelah dilakukan uji validitas, langkah selanjutnya adalah melakukan uji reliabilitas data yaitu dengan melihat nilai cronbach's alpha. Jika nilai Cronbach's alpha lebih besar dari 0,6 maka kuesioner penelitian tersebut dinyatakan reliabel. Hasil pengujian data menunjukkan bahwa nilai cronbach's alpha lebih besar daripada 0,6. Hal ini menunjukkan bahwa data penelitian dinyatakan reliabel. Menurut Nunnally dalam Ghozali (1967) suatu konstruk atau variabel dikatakan reliabel jika memberikan nilai cronbach's alpha $>0,60$.

Tabel 2. Uji Reliabilitas Data

\begin{tabular}{|l|c|c|c|}
\hline \multicolumn{1}{|c|}{ Variabel } & $\begin{array}{c}\text { Alpha } \\
\text { Cronbach's }\end{array}$ & $\begin{array}{c}\text { Batas } \\
\text { Reliabilitas }\end{array}$ & Keterangan \\
\hline SiLPA(Y) & 0,974 & 0,6 & Reliabel \\
Dokumen Perencanaan(X1) & 0,922 & 0,6 & Reliabel \\
Pencatatan Administrasi & 0,947 & 0,6 & Reliabel \\
(X2) & 0,944 & 0,6 & Reliabel \\
Kompetensi SDM(X3) & & & \\
\hline
\end{tabular}

Sumber : data olahan 
Berdasarkan tabel dibawah, maka dapat disimpulkan bahwa semua kategori data reliabel atau telah konsisten jika dilakukan oleh peneliti yang lain atau oleh peneliti yang sama dalam kejadian berbeda. Sehingga data yang dianggap reliabel akan dapat menunjukkan konsistensi responden dalam menjawab hal yang berkaitan dengan konstruk-konstruk pertanyaan yang merupakan dimensi suatu variabel dan disusun dalam suatu bentuk kuesioner.

\section{B.Uji Hipotesis}

Hasil penelitian menunjukkan bahwa faktorPencatatan Administrasi merupakan salah satu faktor yang mempengaruhi tingkat SiLPA. Namun pengaruh faktorPencatatan Administrasi tidaklah sebesar pengaruh faktor Kompetensi SDM (lihat tabel di bawah

Tabel 3.Ringkasan Pengujian Hipotesis

Coefficients $^{\mathrm{a}}$

\begin{tabular}{|c|c|c|c|c|c|c|c|c|}
\hline \multirow{2}{*}{\multicolumn{2}{|c|}{ Model }} & \multicolumn{2}{|c|}{$\begin{array}{l}\text { Unstandardized } \\
\text { Coefficients }\end{array}$} & \multirow{2}{*}{\begin{tabular}{|l} 
Standardized \\
Coefficients
\end{tabular}} & \multirow[b]{2}{*}{$\mathbf{T}$} & \multirow[b]{2}{*}{ Sig. } & \multicolumn{2}{|c|}{$\begin{array}{l}\text { Collinearity } \\
\text { Statistics }\end{array}$} \\
\hline & & B & Std. Error & & & & Tolerance & VIF \\
\hline & (Constant) & -5.392 & 7.244 & & -.744 & .463 & & \\
\hline & Dokumen & .067 & .115 & .051 & .587 & .562 & .464 & 2.157 \\
\hline & Perencanaan & & & & & & & \\
\hline & PencatatanAd & 327 & .158 & .274 & 2.066 & .049 & .199 & 5.014 \\
\hline & $\mathrm{m}$ & & & & & & & \\
\hline & KmptnsiSDM & 684 & .134 & .665 & 5.099 & .000 & .206 & 4.855 \\
\hline
\end{tabular}

a. Dependent Variabel SiLPA

$\begin{array}{ll}\mathrm{R} & =0,953 \\ \text { Adjusted } \mathrm{R}^{2} & =0.899 \\ \text { F value } & =86,58 \\ \text { Sig F } & =0,000\end{array}$

Sumber : Data olahan 
Sesuai dengan hipotesa penelitian yang tertuang pada bab II dimana pendugaan terhadap adanya pengaruh faktorPencatatan Administrasi terhadap SiLPA Pemprov Riau ini terbukti..

\section{a. Pencatatan Adminsitrasi dan SiLPA di Pemerintah Provinsi Riau}

Hasil penelitian ini menunjukkan bahwaPencatatan Administrasi berpengaruh terhadap SiLPA di Pemerintah Provinsi Riau. Ini bisa dilihat pada uji t yang telah dilakukan, yaitu nilai probabilitas variabelPencatatan Administrasi sebesar 0,049 yang lebih kecil dari 0,05. Ini berarti dengan tingkat kepercayaan 95\% variabelPencatatan Administrasi berpengaruh signifikan terhadap SiLPA. Maknanya adalah jikaPencatatan Administrasi meningkat maka SiLPA juga akan meningkat dan begitu juga sebaliknya.

Hasil pengujian terhadapPencatatan Administrasi responden menunjukkan bahwaPencatatan Administrasi responden berada pada kategori baik. Berdasarkan data penelitian yang diperoleh dari 37 responden analisis yang diteliti, untuk 10 item pertanyaan sebagai ukuran

variabelPencatatan Administrasi, nilai kuartil I, kuartil II dan Kuartil III dapat ditentukan melalui perhitungan sebagai berikut :

Skor Minimum $=2 \times 10 \times 37=740$

Skor Maksimum $=4 \times 10 \times 37=1480$

Kuartil II $($ median $)=[740+1480]: 2=1110$

Kuartil $\mathrm{I}=[740+1110]: 2=925$

Kuartil III $=[1480+1110]: 2=1295$

Hasil Tanggapan responden untuk variabelPencatatan Administrasi diperoleh skor sebesar 1340.

Berdasarkan nilai kuartil I, kuartil II dan Kuartil III yang diperoleh selanjutnya data skor tanggapan responden diklisifikasikan dan diperoleh rentang sebagai berikut :

$\begin{array}{lllll}\text { Min } & \text { Q1 } & \text { Q2 } & \text { Q3 } & \text { Max }\end{array}$ 
Rendah Kurang CukupTinggi

I--
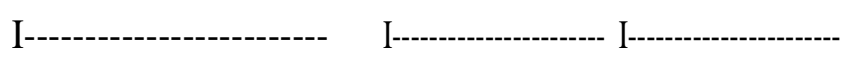

Hasil skor untuk variabel Pencatatan Administrasi (X2) berdasarkan data tanggapan responden yaitu sebesar 1340 berada pada rentang tinggi (1295 - 1480). Penilaian yang diberikan responden memberikan gambaran bahwaPencatatan Administrasi di Pemerintah Provinsi Riau sudah tinggi/ baik. Ini berarti bahwa berdasarkan jawaban yang diperoleh dari responden,Pencatatan Administrasi responden berada pada kategori baik..

\section{b. Kompetensi SDMdan SiLPA di Pemerintah Provinsi Riau}

Sebelum dilakukan uji regresi untuk melihat pengaruh variabel bebas terhadap

variabel terikat, maka dilakukan uji asumsi klasik terlebih dahulu. Hasil pengujian asumsi klasik yang telah dilakukan diatas, menunjukkan bahwa variabel Kompetensi SDMbebas dari segala ketentuan asumsi klasik, yaitu data terdistribusi normal, hal ini dapat terlihat pada diagram normal probability plot. Bebas multikolinearitas dengan nilai VIF $<10(4,855)$ dan nilai Tolerance $>0,1(0,206)$. Bebas heteroskedastisitas yang dapat dilihat pada gambar scaterplot.

Hasil penelitian ini menunjukkan bahwa Kompetensi SDMberpengaruh terhadap SiLPA. Ini bisa dilihat pada hasil uji t yang telah dilakukan terhadap variabel Kompetensi SDM, dimana nilai probabilitas variabel Kompetensi SDMadalah 0,000 yang lebih kecil dari pada 0,05. Ini berarti dengan tingkat keyakinan 95\% variabel Kompetensi SDMberpengaruh siginifikan terhadap SiLPA. Makna nya adalah jika Kompetensi SDMyang diberikan kepada pegawai sudah baik, maka SiLPA juga akan bertambah baik, begitu pula sebaliknya. 
Hasil pengujian terhadap variabel Kompetensi SDMmenunjukkan bahwa Kompetensi SDMyang diberikan pada pegawai sudah baik. Berdasarkan data penelitian yang diperoleh dari 37 responden analisis yang diteliti, untuk 10 item pertanyaan sebagai ukuran variabel Kompetensi, nilai kuartil I, kuartil II dan Kuartil III dapat ditentukan melalui perhitungan sebagai berikut :

Skor Minimum $=2 \times 10 \times 37=740$

Skor Maksimum $=4 \times 10 \times 37=1480$

Kuartil II $($ median $)=[740+1480]: 2=1110$

Kuartil $\mathrm{I}=[740+1110]: 2=925$

Kuartil III $=[1480+1110]: 2=1295$

Hasil Tanggapan responden untuk variabel Kompetensi SDMdiperoleh skor sebesar 2625 ( lihat lampiran)

Berdasarkan nilai kuartil I, kuartil II dan Kuartil III yang diperoleh selanjutnya data skor tanggapan responden diklisifikasikan dan diperoleh rentang sebagai berikut :

Min

Q1 Q2

Q3

$\operatorname{Max}$

Rendah

Kurang

Cukup

Tinggi

740

925

1110

1295

1480

I-

I-

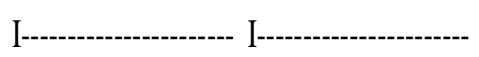

Hasil skor untuk variabel Kompetensi SDM (X3) berdasarkan data tanggapan responden yaitu sebesar 1395 berada pada rentang tinggi (1295 - 1480). Penilaian yang diberikan responden memberikan gambaran bahwa Kompetensi SDM pada Pemerintah 
Provinsi Riau sudah tinggi/ baik. Ini berarti bahwa berdasarkan jawaban yang diperoleh dari responden, Kompetensi SDMresponden berada pada kategori baik.

\section{c. Dokumen Perencanaan dan SiLPA di Pemerintah Provinsi Riau.}

Sebelum dilakukan uji regresi untuk melihat pengaruh variabel bebas terhadap

variabel terikat, maka dilakukan uji asumsi klasik terlebih dahulu. Hasil pengujian asumsi klasik yang telah dilakukan diatas, menunjukkan bahwa variabel Kompetensi SDMbebas dari segala ketentuan asumsi klasik, yaitu data terdistribusi normal, hal ini dapat terlihat pada diagram normal probability plot. Bebas multikolinearitas dengan nilai VIF $<10(2,157)$ dan nilai Tolerance $>0,1(0,464)$. Bebas heteroskedastisitas yang dapat dilihat pada gambar scaterplot.

Hasil penelitian ini menunjukkan bahwa Dokumen Perencanaan tidak mempunyai pengaruh yang signifikan terhadap SiLPA di Pemerintah Provinsi Riau. Ini bisa dilihat pada uji t yang dilakukan terhadap variabel Dokumen Perencanaan dimana nilai probabilitas variabel Dokumen Perencanaan adalah 0,587 yang mana lebih besar dari pada nilai batas probabilitas 0,05 . Ini berarti bahwa dengan tingkat keyakinan 95\% variabel Dokumen Perencanaan tidak berpengaruh signifikan terhadap SiLPA Pemerintah.

Hasil pengujian terhadap variabel Dokumen Perencanaan menunjukkan bahwa Dokumen Perencanaan berada pada kategori baik. Berdasarkan data penelitian yang diperoleh dari 37 responden analisis yang diteliti, untuk 12 item pertanyaan sebagai ukuran variabel Dokumen Perencanaan, nilai kuartil I, kuartil II dan Kuartil III dapat ditentukan melalui perhitungan sebagai berikut :

Skor Minimum $=2 \times 12 \times 37=888$

Skor Maksimum $=4 \times 12 \times 37=1776$

Kuartil II $($ median $)=[888+1776]: 2=1332$

Kuartil $\mathrm{I}=[888+1332]: 2=1110$

Kuartil III $=[1776+1332]: 2=1554$

Hasil Tanggapan responden untuk variabel sikap displin diperoleh skor sebesar 1611. 
Berdasarkan nilai kuartil I, kuartil II dan Kuartil III yang diperoleh selanjutnya data skor tanggapan responden diklisifikasikan dan diperoleh rentang sebagai berikut :

Min

Q1

Q2

Q3

$\operatorname{Max}$

Rendah

Kurang

CukupTinggi

888

1110

1332

1554

1776

$\mathrm{I}-$

I- -

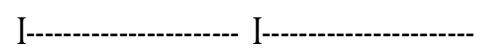

Hasil skor untuk variabel Sikap Dokumen Perencanaan(X1) berdasarkan data tanggapan responden yaitu sebesar 1611 berada pada rentang tinggi (1554 1776). Penilaian yang diberikan responden memberikan gambaran bahwa Dokumen Perencanaan pada Pemerintah Provinsi Riau sudah baik. Ini berarti bahwa berdasarkan jawaban yang diperoleh dari responden, Dokumen Perencanaan responden berada pada kategori baik.

\section{d. Dokumen Perencanaan,Pencatatan Administrasi dan Kompetensi SDMsecara simultan (bersama-sama) terhadap SiLPA.}

Untuk melihat pengaruh variabel bebas secara bersama-sama terhadap variabel terikat maka dapat dilihat pada hasil uji F. Dari uji Simultan atau F test, didapat $\mathrm{F}$ hitung dengan tingkat signifikan 0,000. Karena probabilitas 0,000 lebih kecil daripada 0,05 maka hasil dari model regresi menunjukkan bahwa ada pengaruh kualitas Dokumen Perencanaan,Pencatatan Administrasi dan Kompetensi SDMdan secara simultan terhadap SiLPA di Pemprov Riau. Berdasarkan hasil uji hipotesis yang telah dilakukan maka model penelitian adalah sebagai berikut :

$\operatorname{SiLPA}(Y)=-5,392+0,067 \mathrm{X}_{1}+0,327 \mathrm{X}_{2}+0,684 \mathrm{X}_{3}+\mathrm{e}$

Dimana: 
$\mathrm{Y}=\mathrm{SiLPA}$

$\mathrm{X} 1$ = Dokumen Perencanaan

$\mathrm{X} 2$ =Pencatatan Administrasi

X3 = Kompetensi SDM

Persamaan regresi tersebut diinterpretasikan sebagai berikut:

1) Konstanta sebesar $-5,392$ artinya apabila Dokumen Perencanaan,Pencatatan Administrasi dan Kompetensi SDMbernilai nol, maka SiLPA akan bernilai sebesar -5,392

2) Koefisien regresi Dokumen Perencanaan sebesar 0,067 artinya apabila Dokumen Perencanaan meningkat 1 satuan, akan berdampak pada peningkatan SiLPA sebesar 0,067 satuan. Nilai tersebut adalah rumusan statistik dalam melihat besaran pengaruh Dokumen Perencanaan terhadap SiLPA jika dinyatakan dengan angka.

3) Koefisien regresiPencatatan Administrasi sebesar 0,327 artinya apabilaPencatatan Administrasi meningkat 1 satuan, akan berdampak pada peningkatan SiLPA sebesar 0,327 satuan. Nilai tersebut adalah rumusan statistik dalam melihat berapa besar pengaruhPencatatan Administrasi terhadap SiLPA jika dinyatakan dengan angka.

4) Koefisien regresi Kompetensi SDMsebesar 0,684 artinya apabila Kompetensi SDMmeningkat 1 satuan, akan berdampak pada peningkatan SiLPA sebesar 0,684 satuan. Nilai tersebut adalah rumusan statistik dalam melihat berapa besar pengaruh Kompetensi SDMterhadap SiLPA jika dinyatakan dengan angka.

Dari persamaan di atas, dapat dilihat bahwa koefisien dari semua variabel independen yaitu Dokumen Perencanaan,Pencatatan Administrasi dan Kompetensi SDM menunjukkan angka positif. Berarti bahwa hubungan antara variabel Dokumen Perencanaan,Pencatatan Administrasi dan Kompetensi SDMdengan SiLPA adalah positif. Artinya semakin tinggi variabel Dokumen Perencanaan,Pencatatan Administrasi dan Kompetensi SDMsecara bersama-sama 
maka semakin tinggi SiLPA. Ini juga menjawab rumusan masalah yang telah dipaparkan pada Bab 1 bahwa Dokumen Perencanaan, Pencatatan Adminsitrasi dan Kompetensi SDMsecara simultan berpengaruh terhadap SiLPA .

Namun faktorPencatatan Administrasi adalah faktor yang lebih berpengaruh terhadap SiLPA dibandingkan dengan 2 faktor lainnya yaitu Kompetensi SDMdan Dokumen Perencanaan. Hal ini disebabkan karenaPencatatan Administrasi kadang menjadi syarat utama dalam rekruitmen kepegawaian terutama terkait dengan lowongan kerja.

\section{e. Uji Koefisien Determinasi}

Nilai R square $\left(\mathrm{R}^{2}\right)$ atau nilai koefisien determinasi pada intinya mengukur seberapa jauh kemampuan model dalam menerangkan variasi variabel dependen. Nilai $\mathrm{R}^{2}$ adalah diantara nol dan satu. Nilai $\mathrm{R}^{2}$ yang kecil berarti kemampuan variabel-variabel independen

dalam menjelaskan variasi variabel dependen sangat terbatas. Nilai yang mendekati satu berarti variabel-variabel independen memberikan hampir semua informasi yang dibutuhkan untuk memprediksi variasi variabel dependen. Secara umum $\mathrm{R}^{2}$ untuk data silang (cross section) relatif rendah karena adanya variasi yang besar antara masing-masing pengamatan, sedangkan untuk data runtun waktu (time series) biasanya mempunyai koefisien determinasi yang tinggi.

Jika independen variabel lebih dari satu, maka sebaiknya untuk melihat kemampuan variabel memprediksi variabel dependen, nilai yang digunakan adalah nilai adjusted $\mathrm{R}^{2}$. Nilai adjusted $\mathrm{R}^{2}$ sebesar 0,899 mempunyai arti bahwa variabel dependen mampu dijelaskan oleh variabel independen sebesar 89,9\%. Dengan kata lain $89,9 \%$ perubahan dalam SiLPA mampu dijelaskan variabel Dokumen Perencanaan,Pencatatan Administrasi dan Kompetensi SDM. Dan sisanya sebesar $10,1 \%$ dijelaskan oleh faktor lain yang tidak diikutkan dalam penlitian ini.

\section{KESIMPULAN DAN SARAN}

Setelah dilakukan analisis dan pembahasan terhadap hasil penelitian serta pengujian hipotesis sebagaimana diuraikan pada BAB IV, maka pada bab ini dibuat kesimpulan dan saran yang dapat diberikan dari hasil penelitian yang telah dilakukan. 


\section{Kesimpulan}

Dari hasil pengolahan data yang telah dilakukan pada bab sebelumnya, maka peneliti dapat menyimpulkan hal-hal sebagai berikut :

1. Hasil analisis data menunjukkan bahwa variabel bebas Dokumen Perencanaan,Pencatatan Administrasi dan Kompetensi SDMsecara simultan berpengaruh positif secara signifikan terhadap SiLPA di Pemerintah Provinsi Riau. Ini berarti bahwa jika variabel bebas yaitu Dokumen Perencanaan,Pencatatan Administrasi dan Kompetensi SDM bertambah secara bersama-sama, maka akan memberikan pengaruh yang signifikan terhadap SiLPA di Pemerintah Provinsi Riau dan begitu juga jika terjadi hal sebaliknya.

2. Hasil analisis data menunjukkan bahwa variabel bebasPencatatan Administrasi dan Kompetensi SDMsecara parsial memiliki pengaruh yang signifikan terhadap SiLPA di Pemerintah Provinsi Riau. Hal ini berarti bahwa jika masingmasing variabel Pencatatan Administrasi bertambah baik dan variabel Kompetensi SDMjuga bertambah baik, maka hal ini akan berpengaruh signifikan terhadap meningkatnya SiLPA di Pemerintah Provinsi Riau, begitu juga jika hal ini terjadi sebaliknya. Sedangkan variabel bebas

Dokumen Perencanaan secara parsial tidak memiliki pengaruh yang signifikan terhadap SilPA. Ini berarti bahwa jika variabel Dokumen Perencanaan bertambah baik maka hal ini tidak akan berpengaruh signifikan terhadap SiLPA di Pemerintah Provinsi Riau, dan begitu juga jika terjadi hal sebaliknya.

\section{Saran}

Dalam rangka perbaikan SiLPA di Pemerintah Provinsi Riau, hendaknya memperhatikan faktor-faktor berupa Dokumen Perencanaan,Pencatatan Administrasi dan Kompetensi SDM agar dapat memperoleh hasil yang lebih maksimal.

\section{DAFTAR PUSTAKA}


Centre for Democracy and Development (2005), A Handbook on Budgeting : A Guide to the Due Process Approach, Rehoboth Publishing, Lagos.

Churchill, Gilbert A., Jr (2001), Dasar-Dasar Riset Pemasaran, Edisi 4, Jilid I, Erlangga, Jakarta.

Ditjen Perbendaharaan (2009), Modul Pengelolaan Keuangan Pada Satuan Kerja. Ditjen Perbendaharaan, Kementerian Keuangan RI, Jakarta.

El-Mefleh, Muhannad (2002). "Consequences of Globalization For Developing Economies," Journal of American Association of Behavioral and Social Sciences. $\quad$ [on-line]. Available: http://aabss.org/journal2002/ElMefleh.htm.

Hair, Jr. Joseph F. Rocph E. Anderson, R.,E., Tatham,RL., dan Black W.C., (1995), Multi Variate Data Analysis, Fourth Edition,New Jersey, Prentice Hall.

Hart, Michael H. (1992), 100 Peringkat Orang Paling Berpengaruh dalam Sejarah, Carol Publishing Group/Citadel Press.

Mankiw, N. Gregory, (2003). Teori Makroekonomi, Edisi kelima. Penerbit

Erlangga, Jakarta. Murwanto, Rahmadi (2005), Materi Pokok Pengelolaan Keuangan Negara, Pusdiklat

Pegawai, BPPK, Jakarta.

Permadi, Bambang (1992), “AHP”, PAU-EK-UI, Jakarta.

Radev, Dimitar and Khemani, Pokar (2009), Commitment Controls, International Monetary Funds, New York.

Samuelson, Paul A. dan Nordhaus, William D., (2003). Ilmu Mikroekonomi, Edisi 17. PT.

Media Global Edukasi, Jakarta.

Williams, Mike (2004), “Government Cash Management Good and Bad Practice", available at http://treasury.worldbank.org/web/pdf/williams_technote.pdf.

Yamin, Sofyan, \& Kurniawan, Heri (2009), SPSS Complete: Teknik Analisis Statistik Terlengkap dengan Software SPSS, Salemba Infotek, Jakarta. Undang- 
Undang No.17 Tahun 2003 tentang Keuangan Negara. Undang-Undang No.1 Tahun 2004 tentang Perbendaharaan.

Peraturan Pemerintah Nomor 20 Tahun 2004 tentang Rencana Kerja Pemerintah (RKP). Peraturan Presiden No. 54 Tahun 2010 tentang Pengadaan Barang/Jasa Pemerintah. Peraturan Menteri Keuangan Nomor 134/PMK.06/2005 tentang Pedoman Pembayaran Dalam Pelaksanaan Anggaran Pendapatan dan Belanja Negara.

Peraturan Menteri Keuangan Nomor 131/PMK.01/2006 tentang Organisasi dan Tata Kerja Departemen.

Peraturan Menteri Keuangan Nomor 91/PMK.06/2007 tentang Bagan Akun Standar. Peraturan Menteri Keuangan Nomor 192/PMK.05/2009 tentang Perencanaan Kas. Peraturan Menteri Keuangan Nomor 03/PMK.05/2010 tentang Pengelolaan

Kelebihan/Kekurangan Kas Pemerintah.

Peraturan Menteri Keuangan Nomor 170/PMK.05/2010 tentang Penyelesaian Tagihan Atas Beban APBN Pada Satuan Kerja.

Peraturan Menteri Keuangan Nomor 100/PMK.02/2010 tentang Standar Biaya Tahun Anggaran 2011.

Peraturan Menteri Keuangan Nomor 49/PMK.02/2012 tentang Tata Cara Revisi Anggaran Tahun Anggaran 2012.

Peraturan Direktur Jenderal Perbendaharaan Nomor PER-66/PB/2005 tentang Mekanisme Pelaksanaan Pembayaran Atas Beban APBN 